\title{
Instances of powerful family bond in Soyinka's The Swamp Dwellers
}

\author{
Muhammad Mushfiqur Rahman \\ Lecturer, The Department of English, Noakhali Science And Technology University, Sonapur, Noakhali-3814 \\ Bangladesh
}

\begin{abstract}
The Swamp Dwellers is a play of universal appeal. It talks about remote rural and urban society; family life; confrontation of old and new society; psychological conflicts between old and young generations; love for modernity and love for the swamp; the supernatural; unfavourable forces of nature; and so many problems. I have come across a good number of articles and researches on The Swamp Dwellers. Among the researches and various articles on the play, it is hardly found any focus on family ties, love for family, hints of love in trivial squabble between the married in the play. Whenever they speak of their twin sons, Awuchike and Igwezu, Makuri and Alu are seen constantly at each other's throats. But their tiff bears the testimony of deep love for each other and for their future generations, and exhibits great concern for family ties that were in vulnerable condition during the transitional period in the post colonial African states. Akinwande Oluwole Wole Soyinka vividly portrays such family relationships, the individual and socio-cultural tensions pervading in Nigeria in his widely read The Swamp Dwellers. The patches of stories tremendously adorned in the play give a glimpse of family bond throughout the play. The target of this study is to discover the examples of family ties depicted, hinted, and embedded in the play.
\end{abstract}

Keywords: Family; bondage; tiff, rural life; urban life; tension.

\section{Introduction}

It is assumed that The Swamp Dwellers by Akinwande Oluwole Wole Soyinka widely known as Wole Soyinka focuses the life and culture of an African society, but the play goes beyond the border of a particular area. It expands the border of readers' knowledge, and deals with tensions, problems, conflicts, calamities, and struggles ever-present in human community across the world. The playwright through his powerful imagination has made the language of the play metaphorical, and we have got bundles of images reflecting his individual outlook of human life. His approach is not only of sociological sense, but of human beings. The characters presented in The Swamp Dwellers happen to exist in a particular place and time, but the universally significant themes soars the play to a great height. The backbone of his writings, especially The Swamp Dwellers, may be the culture of Yoruba, but the play excels the demarcation and falls in the stream of international movements for humanity. On the other hand, out of all these widely discussed themes some instances of powerful family bond can be discovered through an extensive and analytical study of the play.

\section{Thematic View Of The Play}

A dramatist's criticism of life is most fully embodied in the spirit and tendency of the action (Hudson, 258). Wole Soyinka in The Swamp Dwellers criticizes the life and culture of human community of a particular African state. Although the spirit and tendency of the action is of Nigerian Yoruba community, the universal appeal for humanity all over the world has explicitly been demonstrated in the play. The Swamp Dwellers is primarily concerned about social changes. An easy access to abruptly abundant oil has caused the social changes and has an impact on human relationships in many African countries especially in Nigeria during mid twentieth century. The play demonstrates how a money-making society is ruined, and falls into a deep tension, disappointment and frustration. The play concentrates on the conflict between the old and the young who are constantly approaching for better life. The clash between custom and innovation is also reflected in the play. It also investigates the existentialist elements, and finds parity between the old and the new. It focuses the struggle of human beings against the unfavourable forces of nature such as 'marsh', 'swamp', 'excessive water', 'rain', 'river', 'serpent', etc. Moreover, the play involves man's avarice and greed. The priest Kadiye becomes fatter with gifts demanded in the name of the serpent. The serpent is pacified whenever his high priest Kadiye receives gifts from the swamp dwellers.

Igwezu becomes shocked to see himself in a dilemma of two cultures- the city one and the rural one. Two cultures have made him a union chamber causing deep frustration to him in the long run (The Toronto Sun). Through the depiction of transitional aspects, Soyinka's endeavour is to strengthen the sense of nationality 
among the frustrated Yoruba community of Nigeria. Soyinka is encouraged by Paul Gilory's assertion, a nation is created through elaborate cultural, ideological and political processes which culminate in the individual's feeling of connectedness to other national subjects and in the idea of a national interest that transcends the supposedly petty divisions of class, region, dialect or caste (McLeod, 75).

\section{Squabbles Between Alu And Makuri}

In the very opening scene of the play, we see the hints of verbal bicker between the two old marriedAlu and Makuri. Alu seems more impatient than Makuri, and she is constantly nagging in the households. Alu has been waiting for long for her dear son and in her every household work she attempts to peep the doorways with great expectations of their son's return. Even the play starts with her question mingled with eagerness for their son:

Alu: Can you see him?

(Soyinka, 1974)

Her insinuating comment on Makuri's attitude towards their expatriate son apparently shows bitter relations with her husband. On the other hand, Makuri's instant response deepens tensions among the readers and the audience.

Alu: If you had any good at all in you, you'd go and look for him.

Makuri: And catch my death of cramp? ... what's preventing you from going?

(Soyinka, 1974)

A minute reading discovers how strong relations they maintain with each other. Makuri even addresses his wife 'a fraud'. She also has serious complaints against Makuri of making her 'a liar'.

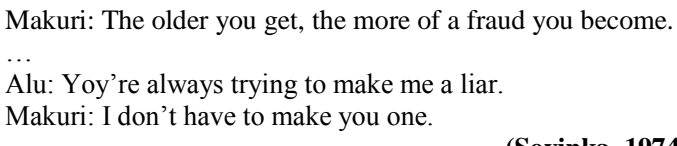

Alu speaks ill of Makuri and it is revealed when she addresses him as 'Frog-face'. The indication of their son's death lies in their conversation. Alu humorously says that Makuri is dead person as he is not looking for their son. When Alu angrily slaps herself on the arm to prevent the fly from biting it Makuri insinuates of her old age and decaying health.

Makuri: Don't tell me now that a fly has been trying to suck blood from your dried-up veins.

(Soyinka, 1974)

\section{Tensions of Alu And Makuri}

Makuri and Alu express their deep concern for their son, Awuchike. They have a continuous argument over his disappearance from home. No one knows about his existence. But a true mother in Alu is in action. She thinks her son is no more, but she is constantly pressing an earnest request to Makuri to find out Awuchike. Makuri's assumption is that Awuchike has gone to the city for a better life. Awuchike's absence in the village and home creates tensions among the swamp dwellers. On the other hand, his parents, out of tension and anxiety, engage themselves in constant oral fighting. Their argumentative conversation develops the story.

\section{Love Between Awuchike And Desala}

From Alu's clue in her dialogue with Makuri, we get an indication of love between Desala and Awuchike. One might discern faults in Desala's anticipation from her would-be husband of thriving urban life, and convict Desala, Awuchike's wife, of breaking the tie between Awuchike and his parents as well as of the family. Desala might have love for an urban life but her love for Awuchike is exposed when she wants to get him more intimately not in the swamp but in the city, as if they would make a loving and prosperous world together there. On the contrary, Awuchike is also a highly ambitious young man. He is fed up with the swamp life and hardship. Therefore, he has gone to the city for fortune. His love for Desala and dream for living together in private away from his root is more active than his fortune-seeking. The money he earns, he earns only for comforts and to win Desala's love. He loves Desala. That is why he loves to make money. One might blame Awuchike for his motivated attempt to leave his own parents in the swamp; to break the conventional family bond; to ignore culture and tradition; and to avoid rural life. But it should be noted that he breaks a family tie only to tie another one, the younger one. His family tie with Desala is so strong that he even leaves his 
parents, and ignores the socio-cultural practices to win the love of Desala; he shows honesty to his love and beloved by shifting himself from the swamp to the urban. In a dialogue Alu reveals the secret:

Alu: ... she (Desala) made him (Awuchike) promise to take her there (the city) before she would wed him.

(Soyinka, 1974)

The anxieties in Alu and Makuri for their son show their love for extended family with sons and daughters-in-law. In the very opening line Alu yearns for her son Awuchike who has left for an urban life with more comforts and money;

$$
\text { Alu: Can you see him? }
$$

(Soyinka, 1974)

In this question, Alu's expectation for her lost son is vividly exposed. Makuri is also worried about Awuchike's existence in the city. He speaks of the young with a shifting attitude:

Makuri: ... They are no sooner born than they want to get out of the village as if it carried a plague.

(Soyinka, 1974)

But Makuri's fatherly affection is focused when we see him speaking of Awuchike's life and death. Alu was constantly insisting on Makuri's no-attempt peculiarity but he refused to perform any funeral rituals for Awuchike. Because he loves his son; he loves his tradition; he loves his family; and he loves to pacify Alu's anxiety over Awuchike's life. He assumes that Awuchike is still alive despite Alu thinks otherwise. Makuri in his words:

Makuri: Dead men don't go to the city. They go to hell.

(Soyinka, 1974)

He says so because he wants to soothe Alu's anxiety over Awuchike's disappearance. Makuri defends his son's position by saying:

Makuri: ... Awuchike got sick of this place and went into the city.

(Soyinka, 1974)

\section{Love And Bond Found In Alu And Makuri}

The famous essayist Francis Bacon in his 'Of Parents and Children' emphasizes the importance of choosing children's profession by their parents not by themselves. Bacon says, 'Let parents choose betimes the vocations and courses they mean their children should take' (Scott, 132). But we observe in the play that parents hardly have their control over the sons. Moreover, they are found in the midst of calamities made by nature to some extent and mostly by their twin issues. They have failed to hold the bridle of the young. But they possess unbridled affection for the twins. On the other hand, Makuri and Alu are engaged in nonstop tiff on trivial matters. But the instances of such trivial matters cumulatively express a great concern for their twins. They are alienated in the swamp where even their sons do not feel interested to live and accompany them. Makuri continues his loving words to Alu while expressing his distress caused by their sons' ambitious immigration to the urban:

Makuri: ... if they knew. If only they could see me take you out into the mangrove,and I so strong that I could make you gripe and swear and sink your teeth into my cheeks.

(Soyinka, 1974)

What a lovely expression of love it is! His love for Alu makes him more nostalgic, and more affiliated with family bond even in the transitional Afircan society. We get more instances of love and bond between Alu and Makuri in the following dialogues:

Alu: You were always one for boasting.

Makuri: And you with your eyes shut so tight that I thought the skin would tear itself. Your eyes always shut, so that up till this day you cannot tell what I looked like when the spirit took me, and I waxed as hot as the devil himself.

Alu: Be quiet.

Makuri: You never feared the swamp then. You could walk across it day and night and go to sleep in the middle of it.... Alu, do you remember our wedding night?

(Soyinka, 1974) 
These dialogues between the old married convey love affair that was strong and powerful even in the swamp and in hardship. Their past is reminded because their sons' eccentricity to leave the swamp and to live in the urban, and because there is now a big gulf created between them and their twins. They were anxious about the twin sons and their old tradition, culture, society, and family tier. Throughout the play we come across their love for tradition, culture, and family tie.

\section{Conclusion}

Wole Soyinka mostly rely on ritual and traditional sources for composing the play but this does not make his play traditional, rather this trend of writing play goes beyond the border, and gets universal recognition in perspective of humanity. The playwright uses the raw materials of myths, and certain formal properties to furnish the play producing something new and sometimes wholly unexpected. Although the play sometimes exposes banal elements of human affairs, it gradually unravels the dramatist's inner side and the universal complexities humans face across the globe. The banal elements which have stitched the play ultimately portray love for trends and tradition; love for stability of human beings; and love of family, the extended family. The dialogues exchanged in the play demonstrate strong family bond and love yearned by the chief characters.

\section{Works Cited}

[1]. Dzegueze, Kaspars. "Value from black company." Toronto Sun 11 March 1975.

[2]. Hudson, William Henry. An Introduction to the Study of Literature. Calcutta: Radha Publishing House, 1997.

[3]. McLeod, John. Beginning Postcolonialism. Manchester: Manchester University Press, 2007.

[4]. Scott, Mary Augusta. The Essays of Francis Bacon: Edited with Introduction and Notes. New York: Charles Scribner's Sons, 1908.

[5]. Soyinka, Wole. Collected Plays: Volume I: A Dance of the Forests; The Swamp Dwellers; The Strong Breed; The Road; The Bacchae of Euripides. Oxford: OUP, 1974 